ZalącZnils

DOI 10.21697/zk.2021.8.30

Uznanie autorstwa-Użycie niekomercyjne-Bez utworów zależnych

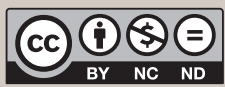

Załącznik Kulturoznawczy 8/2021

KOMENTARZE. OPINIE. GLOSY

\title{
THE ADDED VALUE OF OSCARS AND FESTIVAL AWARDS
}

EWA MAZIERSKa

$$
\begin{aligned}
& \text { University of Central Lancashire } \\
& \text { School of Arts and the Media } \\
& \text { EHMazierska@uclan.ac.uk } \\
& \text { ORCID number: 0000-0002-4385-8264 }
\end{aligned}
$$

Every year, the announcement of nominations for the Academy Awards, popularly known as Oscars, encourages discussion about the value of film awards and their 'justice'. Do awards matter? Is there more to them than the awards themselves? Do awards received at film festivals have the same function and value as Oscars? In this article, I will try to answer these questions by looking at several aspects of awards: their effect on the monetary profit made by the winning films, their effect on the construction of the film canon and the 'cinematic map' of the world. I will also consider the argument that film awards have lost some of their value in recent years. My article is based on secondary research about Oscars and film festivals, a large part of which is based on journalistic sources, reflecting the fact that much of the data is new and hence has not yet been properly digested by the academic community.

\section{PROFITING FROM THE OSCARS}

The short answer to the question of whether the Academy Awards pay is: 'yes, they do'. Oscars are important for films and filmmakers, especially directors, producers, actors and scriptwriters. They add about $\$ 20$ million to the gross of a film and increase the market value of the directors and actors. The King's Speech (2010), directed by Tom Hooper, for example, was initially projected to gross just $\$ 30$ million, but after its subsequent nomination and victory, it went on to make more than $\$ 400$ million in the box office (Lee 2020).

The addition of commercial value to Oscar films takes place in several stages, some of which precede the Oscar ceremony. Firstly, the very 
expectations that a given film will be nominated for an Oscar, lead to investment in its promotion, which translates into larger audiences (on the relation between marketing and the sale of films see Kahn 1986). Secondly, studios, on average, spend an extra $\$ 10$ million just to run an Oscar campaign (Lee 2020). Such investment not only helps certain films to win Oscars, but also creates a 'buzz' around them and convinces important people in the industry to watch them. Then, there are the nominations, which create a 'post-nominations bounce' by making ordinary viewers aware of the films, which they would otherwise not watch at all and drawing distributors' attention to them. Finally, there is the Oscar ceremony, which announces some films as the best produced in a given year. This brings the issue of the relative merit of an Oscar award in relation to an Oscar nomination. Dean Keith Simonton argues that

The official nomination and voting procedures are not designed to yield an optimal outcome. On the one hand, the process of making nominations in most categories is often restricted to the members of the corresponding branch of the Academy. For example, only directors can nominate the candidates for Best Achievement in Directing. It makes perfectly good sense to have the nominations confined to the membership with the greatest expertise. On the other hand, the ballots for the final awards for almost all categories are distributed to the general membership, regardless of the branch to which the member belongs. Hence, the final result is contingent on votes that are appreciably less informed than is the case for the initial nominations. Therefore, it is conceivable that Oscar nominations are more indicative of true cinematic accomplishment in a particular category than are the Oscar awards themselves. The awards might even worsen the correspondence between the honors and genuine merit, like sprinkling extra salt in an otherwise perfect dish. (Simonton 2004: 164-65)

A sign that nominations are more important than actual Oscars is that the post-nominations 'bounce' tends to be stronger than after the reception of anOscar. For example, 1999's American Beauty by Sam Mendes earned \$55 million after the nomination; 1998's Shakespeare in Love by John Madden earned an extra $\$ 63$ million. This was more than the added value these films received after the Oscars (Galloway 2020).

Oscars also bring perks to filmmakers engaged in their production. 'Winners do get a none-too-shabby swag bag. In 2016, it contained more 
than $\$ 220,000$ of gifts including a 10-day VIP trip to Israel (worth $\$ 55,000$ ) and $\$ 300$ worth of personalized M\&M's. This year's bag [in 2018] contains a 12-night holiday in Tanzania, Rogue Maple Syrup and a DNA health and ancestry kit' (Teodorczuk 2018). These awards are probably most important for the previously unknown actors, as they lift them to the position of stardom, bringing new films offers and other lucrative contracts, especially in advertising. Many A-listers, actors, directors and some writers receive a bonus if they're nominated or win: $\$ 100,000$ for a nomination and $\$ 250,000$, if they win (Galloway 2020). These figures might seem high to the 'lay audience', but are rather modest, if we take into account the earnings of Hollywood stars, who often get paid several million dollars per film. Moreover, these bonuses are meager compared with their share in the films' profit. However, these sums translate into new film offers and keeping the limelight on popular actors.

Oscars also matter because they correspond best with other important awards, such as those by the Academy of Motion Picture Arts and Sciences, Hollywood Foreign Press Association, British Academy of Film and Television Arts, New York Film Critics Circle, National Board of Review, National Society of Film Critics and Los Angeles Film Critics Association as well as more specialized awards granted by guilds and societies (Simonton 2004: 165).

For films and filmmakers coming from peripheral countries, awards have an additional value in putting their country on the 'cinematic map' of the world. This was the case of Czechoslovakia in the 1960s, which won two Oscars for The Shop on Main Street (1965), directed by Ján Kadár and Elmar Klos and Closely Observed Trains (1966), directed by Jiří Menzel, respectively in 1966 and 1968. These wins drew attention to the phenomenon of Czechoslovak New Wave and facilitated successful international careers of a few Czechoslovak directors. One such beneficiary of that attention was Miloš Forman, who went on to direct One Flew Over the Cuckoo's Nest (1975), for which he won the best director award at the 1976 Oscars. Equally, the Oscar for a South Korean film Parasite (2019), directed by Bong Joon-ho, which resulted in increased interest of Western media in Korean films and a wider international audience (Bradshaw 2020). It also convinced Netflix to invest $\$ 500$ million in South Korean cinema (Merican 2021). 
Oscars and nominations also correlate positively with later movie guide ratings and are an important factor in a film's longevity. Winners of prestigious awards are more likely to be released on DVD, shown on television and re-released in subsequent decades, as well as become part of the canon. An example is The Sound of Music (1965), directed by Robert Wise, which received five Academy Awards. It is probably the most canonised musical of all time, being selected in 2001 by the United States Library of Congress for preservation in the National Film Registry, as a film which was 'culturally, historically, or aesthetically significant'.

Given that the Oscars matter so much, the question arises how to win them. As has already been indicated, splashing money on publicity and wooing the jurors by inviting them for meals, where they can interact with directors and actors, is a good strategy to achieve this goal. The first film which benefitted from such a targeted campaign was The Deer Hunter (1978) by Micheal Cimino, which won the Best Picture in 1978, and Harvey Weinstein perfected such an effective campaign. It is how Shakespeare in Love took home the 1999 prize instead of Spielberg's Saving Private Ryan, which was an obvious favorite at the time (Buckley 2017; Cunningham 2017; Lee 2020). Another successful strategy is collecting awards at festivals, which I will discuss in the subsequent sections. But what about the films themselves? Is there a recipe for an Oscar film? Many critics agree that there is. The easiest way to win an Oscar or at least to receive an Oscar nomination is to make a 'Holocaust film'. Although there are many Holocaust deniers in the world, this position is not welcome in Hollywood. The list of films which did well thanks to tackling this topic is very long. It includes Steven Spielberg's Schindler's List (1993) (which leads the Oscar pack with nine), Bob Fosse's Cabaret (1972), Alan J. Pakula's Sophie's Choice (1982), Roman Polanski's The Pianist (2002) and Quentin Tarantino's Inglorious Basterds (2009). The list also includes many foreign-language films. This topic prevails in films from Eastern Europe. The first example is the already mentioned Czech film, The Shop on Main Street. Others include Paweł Pawlikowski's Ida (2013) and László Nemes' Son of Saul (2015). There are also some nominees that did not win, like Agnieszka Holland's 1985 Angry Harvest and Lina Wertmuller's 1975 entry Seven Beauties. Interest in the Holocaust reflects the weight of the event itself, seen as unprecedented in human history because of its cruelty. It also points to the composition of the body which 
gives awards. As Anne Thompson observes, many older, Jewish Academy members, who remember World War II, can't get enough of the Holocaust. 'The Jews built the film industry. Since World War II, it's one horror story they've told over and over again' (Thompson 2016). One shall also add that, unlike during the time of the Cold War, when the Holocaust was somewhat controversial in certain parts of Europe, these days it is probably the safest of all historical subjects, as there is nobody who would take the side of Holocaust perpetrators or dispute any data, related to the deaths or suffering of the Jews.

\section{NETWORKING AT FILM FESTIVALS}

Awards at film festivals play a similar function to Oscars, by bestowing prestige and adding monetary value to films. Yet, there are also differences between these awards. The tradition of holding film festivals comes from Europe, rather than the United States and festivals were meant to provide a counterweight to the power of the Academy awards (de Valck 2007). Their origins lie in the 1930s, and especially in recognition of the power of cinema as a means to forge national identity by some European governments, particularly Italy, Germany and Russia. In this spirit, the Venice International Film Festival was created by Giuseppe Volpi, Luciano de Feo, and Antonio Maraini in 1932, as a part of the Venice Biennale, one of the world's oldest art exhibitions, created by the Venice City Council in 1893. Volpi was a wealthy businessman and an avid fascist who worked in Mussollini's government and shared his ambition to create a festival able to compete with the cultural power of Hollywood and to raise Italy's profile as a film powerhouse ('La Biennale di Venezia'). The film festival in the French Riviera city of Cannes, originally slated to take place in 1939, was meant to be a counterweight for the Venice festival. It was designed to celebrate free expression and the films of non-fascist nations. Yet, it had to wait until after the end of WWII, to materialize. In 1946 another European Film Festival was founded, in the Swiss town of Locarno. In 1951, the Berlin International Film Festival was launched, completing the triangle of admittedly the most important film festivals in Europe and the world, along with Cannes and Venice. These festivals were international in nature and championed arthouse cinema. 
It was only in 1978, when the United States founded a festival which in due course would be mentioned in the same breath as Cannes, Venice and Berlin: the Sundance Film Festival. It began in Salt Lake City in August that year as the Utah/US Film Festival in an effort to attract more filmmakers to Utah. Founded by Sterling Van Wagenen, head of Robert Redford's company Wildwood, and John Earle of the Utah Film Commission, it has became forever associated with Robert Redford. The first festival featured films such as Deliverance (1972), directed by John Boorman, Midnight Cowboy (1969), directed by John Schlesinger and Mean Streets (1973), directed by Martin Scorsese, all works marking changes in American cinema, away from movies made for an entire family and shot in the studio, towards films shot on location and touching more controversial subjects. In due course the Sundance Festival would become the main meeting point for creators and distributors of American independent cinema, which can be regarded as an American equivalent of European arthouse cinema. This was cinema operating outside of Hollywood, both from the perspective of the mode of production (small budget, no stars) and geographical distance from California.

The closer we come to the current day, the more film festivals we find in different corners of the world. On different databases (for example 'Festagent'), their numbers reach several thousand. As de Valcks notes:

the number of film festivals has increased significantly from the 1980s onwards and has been characterized by a global dispersion. In the 1980s, the film industry also underwent an important transformation influenced by cable television and (predominantly) video. These two developments led to the creation of the international film festival circuit in which some major festivals operate as market places, cultural capital generators, and agenda setters while the remaining majority focuses on the (thematic) exhibition of (festival) films and, occasionally, the discovery of new talent. Film festivals have been able to multiply because they offer opportunities for film exhibition outside of the regular movie theatre circuit and the regular year round programming rhythm, in particular for films that do not (yet) have the commercial potential to be distributed while they are of special interest to the niche community of film lovers that visit festivals. For films that have already secured distribution before they are screened at festivals, the decision to participate in a specific festival is normally 
taken by the distributor for the territory where the festival will take place. The festival site thus becomes part of the marketing strategy laid out by a distributor. (de Valck 2007: 104). Since de Valck published her book, the relationship between festivals and regular film distributions changed somewhat, in the sense that festivals became not only a way to secure such distribution, but often replaced it. People who attend film festivals these days are less likely to go to see films in normal distribution than in the past. Increasingly, film festivals become also multi-media affairs, including, apart from film screenings, concerts, fine arts and photo exhibitions, as well as theatre performances. Their organisers acknowledge that, as Péter Virginás observes in relation to Transilvania International Film Festival, that 'the festival crowd is not only constituted by avid cinephiles and, at the same time, that cultural consumption preferences may extend beyond cinema' (Virginás 2017). This reflects the trend of 'festivalization of culture', namely reducing culture to extraordinary 'events', which are consumed from time to time, rather than all year round participation (Bennett, Taylor and Woodward 2014). Filmmakers dream about winning prestigious awards at film festivals no less than they dream about winning Oscars. However, winning is not the main reason to attend film festivals; the main one is networking opportunities. It pays off to present one's films there, because festivals are attended by distributors, producers and executives, as well as creative personnel. Distributors allow a greater exposure of films presented at festivals, often in several countries. Producers help finance new projects by promising directors. Festivals also hold workshops for young filmmakers, as well as facilitate their contact with more experienced colleagues, able and willing to offer less formal advice. They are places where one can meet one's future collaborators, such as cinematographers or actors (Brophy 2020). Festivals themselves also create formal or informal networks: they 'talk to each other', as well as compete against each other for prestige. An award at one festival is likely to result in an invitation to another festival or to the same festival in the following year, as festivals like to welcome their filmmakers back for years to come. Awards at the main film festivals provide a good prediction about the chances of a given film to receive Oscars. Take the previously mentioned Ida by Pawlikowski. Before it won the Award for Best Film Not in the English Language at the 68th British Academy Film Awards, it received, among others, the FIPRESCI Special 
Presentations award at the Toronto Film Festival and won festivals in Gdynia, Warsaw, London, Bydgoszcz, Minsk, Gijón, Wiesbaden and Kraków. It was also honored by the national Polish Film Academy as the Best Film of 2013 and the European Film Academy nominated it in seven categories. Subsequently the film won in five of them. It was also selected by the European Parliament for the Lux Prize. With such a 'bag of awards' it was a film which needed to be reckoned with by the Academy members. Unlike Oscar nominations, which are selected by about $6000 \mathrm{film}$ professionals, averaging their preferences, festivals have a small number of independent programmers, who trust their own taste. This taste tends to privilege arthouse films. As a consequence, there is the phenomenon of a 'festival film', which successfully travels the international film festival circuit, but fails to 'make it' outside of the circuit. This phenomenon is supported by research about preferences of cinema audiences. For example, for Polish audiences, awards won at festivals affect their preferences only in $47 \%$, as opposed to genre, with $84 \%$ ('Factors influencing the choice of film to see in the cinema in Poland in 2018'). As Marijke de Valck argues, the festival film 'smoothly fits into the model of auteurs, new waves, discoveries, and political participation, which, in effect, provides a blueprint for filmmakers seeking festival exposure. Successful films on the festival circuit indeed incite entire sets of followers, who try to maximize their chances of success by conforming to the acclaimed films as if they were a magic formula' (Valck 2007: 176). Thus, paradoxically, rather than stimulating innovation and variety in film production, festivals result in the homogenization of cinema, probably to a greater extent than Oscars. This does not mean, however, that each festival 'sings from the same book', so to speak, as they follow specific regional politics, as well being more or less overtly political. For example, neither Venice nor Locarno have ever awarded a prize to a Romanian New Wave film as opposed to Berlin and Cannes. Berlin has awarded three Iranian and one Israeli film since 2010, while filmmakers from these countries received none during the same period in Cannes and Venice.

\section{PROSPERING WITHOUT AWARDS}

Although Oscars and festival awards give us a good insight into the income films make globally and their place in the cinematic canon, they do not guarantee longevity. Equally, there are examples of films and filmmakers 
who prospered despite being repeatedly overlooked by the Academy. This refers to two of the most canonical American films: Citizen Kane (1941) by Orson Welles and Vertigo (1958) by Alfred Hitchcock. Citizen Kane has been regarded as a breakthrough in filmmaking and for many decades was seen as the ultimate masterpiece: the best film ever made (Ebiri 2020). Yet, Citizen Kane failed to win an Oscar for Best Picture and the ceremony of 14th Academy Awards is now considered notable as the year in which it lost to John Ford's How Green Was My Valley and won only one, for Best Original Screenplay. The case of Citizen Kane demonstrates that nominations predict the longevity of the film better than Oscars, as this film was nominated for nine Academy Awards. Vertigo (1958), which upstaged Citizen Kane in the most recent, 2012 British Film Institute's 'Sight \& Sound' poll for the best film ever made, received only two less significant Oscar nominations, both in the technical categories, for Best Art Direction and Best Sound. Another remarkable loser is Singin' in the Rain (1952), a musical directed and choreographed by Gene Kelly and Stanley Donen, which is often regarded as the best musical ever made. This film received only two nominations, for Jean Hagen in the category of Best Supporting Actress and for Best Original Music Score for Lennie Hayton.Although Vertigo did poorly in Oscars, the total number of Oscar nominations (including winners) earned by films directed by Hitchcock is fifty, which is a remarkable achievement. Hitchcock's story points to the previously mentioned rule that nominations give a better insight into the critical standing of the given filmmaker than Oscars. There are other filmmakers who attracted few or no awards and scarce nominations, despite their status as masters of cinema, such as Charlie Chaplin, Fritz Lang and Stanley Kubrick (Kiang and Lyttelton 2014). Another example is Jean-Luc Godard, whose films were consistently omitted from nominations for best foreign film. Godard only received an honorary Oscar in 2010 at a ceremony, which he didn't attend, either because of his advanced age (he was 79 when he received the award), in a more polite reading, or because he didn't have a good opinion about Hollywood cinema (Child 2010). Why did the Academy wait so long to recognize this cinematic genius, who has more volumes dedicated to his art than any other director in the history of cinema and influenced many famous American directors, such as Quentin Tarantino? One answer is that his films are simply too difficult and lack any uplifting messages, appreciated by the Oscar jurors, who prefer films that 
end happily. There is also a (conspiracy?) theory that Godard's sympathy for the plight of Palestine, which is interpreted as anti-Semitism, puts off jurors, many of whom are Jewish (Harris 2010). Yet, more surprisingly, Godard failed to receive many awards at European film festivals either, despite such festivals catering specifically for arthouse films, associated with his name. Paradoxically, this might be the very reason that he was so rarely awarded - it feels like, at least in Europe, he is above the awards - these are more suitable to his 'cinematic children and grandchildren' than to the master himself. Roman Polanski, a director from the same generation as Godard, with equally high critical standing, fared better at Oscars than the latter, receiving six nominations, beginning with his Knife in the Water, in 1964, but still had to wait until he was seventy for his first Oscar for The Pianist, in 2003, which was, predictably, a Holocaust film.

\section{DIMINISHING RETURNS}

While it is acknowledged that Oscars matter, domestically and internationally, it is also argued that the effect of Oscars on film profits has diminished over time, especially in relation to figures on the American market. Before 2000, winning Best Picture could add more than $\$ 100$ million domestically. That's not the case anymore. No best picture winner has earned more than \$100 million domestically since 2012's Argo (which grossed \$136 million); even then, only 4.7 percent of its revenue came after the Oscars' (Galloway 2020).

The real value of the Oscar today lies with the streamers. While Netflix has never released viewing figures for Roma (2018) by Alfonso Cuarón, which won three Oscars in 2019, its marketing campaign moved in lockstep with its awards push to make the movie one of the most talked-about that year. 'This isn't just about subscribers, says one of the industry insiders. It's about legitimacy: being seen in the same league as a Universal or Disney. It's also about hard cash. The day after the Oscar ceremony in which Roma won three statuettes, Netflix saw its stock rise 1.5 percent to $\$ 371.49$. True, the gain faded within hours, but it remained a hugely more valuable company than it had been before' (Galloway 2020). It is worth mentioning that the director of the film emphasized the importance of the film being available for streaming as a sign of democratization of cinema (Butter 2019). The effect of Oscars and festivals on streaming is particularly important since the beginning of 
the Covid-19 pandemic, when cinema theatres have been closed for a long period and the majority of film audiences accessed films through home cinema (Adgate 2020; Rajan 2020). However, even when taking into account the effect of streaming on film consumption, there is a feeling that Oscars are not what they used to be. This is reflected in the figures of television viewers watching Oscar ceremonies. In 2020, the last event available while writing this article, they fell to an all time low ('Oscars 2020: Number of $\mathrm{TV}$ viewers falls to all-time low'). These diminishing returns might reflect problems with the marketing of films and timing of the events, with last year's window between nominations and the awards being particularly tight. But the problem might also have something to do with the awarded films, which receive their trophies for reasons not directly related to their artistic value, but their political leaning. Admittedly, this has been the case for decades, with the Holocaust films being a favorite of the Academy members, as previously mentioned. However, there is a difference between the old and new approach to awards. In the past, there was a relatively narrow group of films which could receive an 'Oscar uplift', thanks to tackling certain topics, such as the Holocaust or other humanitarian disasters. In the last decade and, especially, since 2015, 'when the \#OscarsSoWhite hashtag called out the industry's woeful lack of inclusivity, the show has been transformedpossibly against its(?) will-from a sporadically \#woke statuette dispensary to something bigger' (Raftery 2017). Films aspiring to receive awards are scrutinized from the perspective of their representativeness, understood in intersectional terms, namely reflecting the compositions of specific demographics to which they are addressed, as well as their 'politically correct' content and the way this content is conveyed off-screen. The first means that films need to prove their 'inclusivity', most importantly by including a representative of a marginalized category, such as a black or indigenous actor. This was a factor, for example, in the positive spin of Roma, a nomination for black actress Viola Davis in 2021 or for the Chinese female director Chloe Zhao in the same year. We also observe calls to add gender and racial quotas to the awards. Accepting speeches are now routinely used to prove one's 'correct' political credentials; through, most importantly Trump-bashing (a practice which might have, however, ceased by this point), as well as showing one's support for as many good causes as one can squeeze into the couple of minutes allocated to one's speech, of which 
environmental concerns are most common. By contrast, saying something which is not politically correct, even light-heartedly, as was the case with Lars von Trier, who admitted having Nazi sympathies at Cannes Festival, resulted in banning him from this festival ("Von Trier "persona non grata" at Cannes after Nazi row' 2011). That said, there is an argument that ultimately von Trier's provocations have not affected him negatively. In fact, two years later von Trier used this scandal to promote his new film in Berlin, wearing a 'Persona Non Grata, Official Selection' t-shirt (Wiseman 2014). Moreover, while in the past it did not matter if the personal conduct of the filmmakers behind the films aspiring for awards was less than perfect, this is no longer the case. Such a shift from 'textual to personal', to a large extent happened because Harvey Weinstein, who has left his lasting marks on the race for Oscars, also became the most disgraced inhabitant of Hollywood (Buckley 2017), leaving a deep stain on the institution of Oscars, which the Academy desperately tries to clean. The current situation of Roman Polanski shows how the effort to morally purge the cinema accelerates, paradoxically, in step with the years passing since his rape conviction in 1978, making it increasingly difficult for this director to gain recognition for his new films, even when the critics recognise their high quality, as is the case with $A n$ Officer and a Spy (2019). At the opening press conference of the Venice Festival in 2019, the director of the festival, Alberto Barbera, said that he was convinced he had made the correct choice to include Polanski:

The history of art is full of artists who committed crimes but we have continued to admire their works of art and the same is true of Polanski. He is, in my opinion, one of the last masters in European cinema. We cannot wait 200 years to decide whether his films are great or easily forgotten, an aesthetic judgment needs to be passed at once. (quoted in Bakare 2019) However, this decision led to a backlash on the grounds that Polanski's past disqualifies him from such events. One can expect, that in the future there would be fewer festival programmers like Barbera. Another symptom of trying to receive awards through politics is tiptoeing around the sensibilities of some ethnic and religious groups due to anxiety about offending them (Ebert 2002), like Native and Black Americans in American films, or Muslims in British films. The danger related with such anxiety is producing bland films, which put off viewers due to their predictability and fail to advance the causes of those, whom the films are meant to represent, often by avoiding 
representing them altogether. The danger of changing Oscars and festivals into 'festivals of good intentions' is probably the greatest challenge faced by these institutions.

\section{CONCLUSIONS}

Oscars and film festivals matter, adding monetary and cultural capital to the awarded films. They also help to develop new talent and build the filmmaking community. They are particularly important for artists and film professionals from the cinematic province, which means practically from anywhere outside of the United States, France (the cradle of arthouse cinema) and India. However, the typical nostalgic saying that the 'world is not as it used to be' can also be applied to these events. They offer diminished returns and the Covid epidemic has lowered their value even more.

\section{Works cited}

Adgate, Brad (2020). 'Nielsen: How The Pandemic Changed At Home Media Consumption', Forbes, 21 August, https://www.forbes.com/sites/bradadgate/2020/08/21/nielsen-how-the-pandemic-changed-at-home-media-consumption/?sh=3268b0105a28, accessed 2/04/2021.

Bennett, Andy, Jodie Taylor and Ian Woodward (eds) (2014). The Festivalisation of Culture (Aldershot: Ashgate).

Bradshaw, Peter (2020). 'Classics of modern South Korean cinema - ranked!', The Guardian, 13 February, https://www.theguardian.com/film/2020/feb/13/classics-of-modern-south-korean-cinema-ranked, accessed 2/03/2021.

Brophy, Caroline (2020). 'Why Film Festivals Are Worth It', The Film Fund, 10 August, https://www.thefilmfund.co/why-film-festivals-are-worth-it/\#.YGgNxmhKjFi, accessed 10/03/2021.

Buckley, Cara (2017). 'How Can the Oscars Celebrate in Weinstein's Long Shadow?', The New York Times, 29 November, https://www.nytimes.com/2017/11/29/movies/ harvey-weinstein-victims-oscars.html, accessed 31/03/2021.

Butter, Susannah (2019). 'Roma Director Alfonso Cuaron Interview: "I Was Making Something That Came Directly from Memory"', GoLondon, 31 January, https:// www.standard.co.uk/go/london/film/roma-director-alfonsocuar-n-interview-oscars-a4053931.html (accessed 15 May 2019).

Child, Ben (2010). 'Jean-Luc Godard won't travel to accept honorary Oscar', The Guardian, 7 September, https://www.theguardian.com/film/2010/sep/07/jean-luc-godard-honorary-oscar, accessed 20/03/2021. 
Cunningham, Malorie (2017). 'Oscar campaigns: How they work, why they matter and their questionable tactics', $A B C$ News, 25 February, https://abcnews.go.com/ Entertainment/curtain-art-successful-oscar-campaign/story?id=45666466t, accessed 9/03/2021.

de Valck, Marijke (2007). Film Festivals: From European Geopolitics to Global Cinephilia (Amsterdam: Amsterdam University Press).

Ebert, Roger (2002). 'No place for political correctness in film', Roger.Ebert.com, 18 January, https://www.rogerebert.com/festivals/no-place-for-political-correctness-in-film, accessed 1/04/2021.

Ebiri, Bilge (2020). 'The Rise (and Inevitable Fall) of Citizen Kane As the Greatest Movie Ever Made', Vulture, 4 December, https://www.vulture.com/2020/12/why-is-citizen-kane-the-great-movie-ever-made.html, accessed 19/03/2021.

'Festagent', https://festagent.com/en/festivals, accessed 15/03/2021.

'Factors influencing the choice of film to see in the cinema in Poland in 2018'. Statista. com, https://www.statista.com/statistics/1035259/factors-film-cinema-choice-poland/, accessed 5/04/2021.

Galloway, Stephen (2020). 'How Much Is an Oscar Actually Worth?', The Hollywood Reporter, 9 January, https://www.hollywoodreporter.com/news/how-is-an-oscar-actually-worth-1267462, accessed 19/03/2021.

Harris, Paul (2010). 'Jean-Luc Godard's Oscar rekindles antisemitism row', The Guardian, 14 November, https://www.theguardian.com/film/2010/nov/14/jean-luc-godard-oscar-antisemitism, accessed 6/03/2021.

Kahn, Richard (1986).'Motion Picture Marketing', in Jason E. Squire (ed), The Movie Business Book (London: Columbus Books), pp. 263-72.

Kiang, Jessica and Oli Lyttelton (2014). '20 Celebrated Filmmakers Who Never Won A Best Directing Oscar', IndieWire, 26 February, https://www.indiewire. com/2014/02/20-celebrated-filmmakers-who-never-won-a-best-directing-oscar-88655/, accessed 31/03/2021.

'La Biennale di Venezia', https://www.labiennale.org/en/history-venice-film-festival, accessed 4/03/2021.

Lee, Nathaniel (2020). 'There's a formula to winning the Oscars, and it's all in the statistics', Business Insider, 7 February, https://www.businessinsider.com/oscars-academy-awards-rigged-best-picture-nominations-win-2019-2? $r=\mathrm{US} \& I R=\mathrm{T}$, accessed 10/03/2021.

Merican, Sara (2021). 'Netflix Will Invest \$500 Million In Korean Content This Year', Forbes, 26 February, https://www.forbes.com/sites/saramerican/2021/02/26/ netflix-will-invest-500-million-in-korean-content-this-year/?sh=13cafaeb194b, accessed 16/03/2021.

'Oscars 2020: Number of TV viewers falls to all-time low' (2020), BBC, 10 February, https://www.bbc.co.uk/news/entertainment-arts-51451904, accessed 20/03/2021. 
Raftery, Brian (2017). 'The Oscars Have Always Been Self-Important. Now It's For a Reason', Wired, 24 February, https://www.wired.com/2017/02/oscars-most-important-awards-show/, accessed 20/03/2021.

Rajan, Amol (2020). 'TV watching and online streaming surge during lockdown', $B B C$ News, 5 August, https://www.bbc.co.uk/news/entertainment-arts-53637305, accessed 3/04/2021.

Simonton, Dean Keith (2004). 'Film Awards as Indicators of Cinematic Creativity and Achievement: A Quantitative Comparison of the Oscars and Six Alternatives', Creativity Research Journal, Vol 16, No 2, 2004, pp. 163-172.

Teodorczuk Tom (2018). 'How much economic value do you really get from winning an Oscar?', Market Watch, 3 March, https://www.marketwatch.com/story/ how-much-economic-value-do-you-gain-from-winning-an-oscar-2018-03-02, accessed 28/03/2021.

Thompson, Anne (2016). 'Why Movies Keep Going Back to the Holocaust', Indie Wire, 30 September, https://www.indiewire.com/2016/09/holocaust-movies-oscars-denial-defying-the-nazis-the-sharps-war-ken-burns-1201732059/, accessed 28/03/2021.

Virginás, Péter (2017). 'Romanian and Hungarian film cultures at the Transilvania International Film Festival', NECSUS, 28 May, https://necsus-ejms.org/romanian-and-hungarian-film-cultures-at-the-transilvania-international-film-festival/, accessed 2/04/2021.

'Von Trier "persona non grata" at Cannes after Nazi row' (2011). BBC News, 19 May, https://www.bbc.co.uk/news/entertainment-arts-13452978, accessed 2/04/2021.

Wiseman, Andreas (2014). 'Berlin: Lars von Trier flashes Cannes "Persona Non Grata" shirt', Screen Daily, 9 February, https://www.screendaily.com/news/berlin-lars-von-trier-flashes-cannes-persona-non-grata-shirt/5066499.article, accessed 2/06/2021.

\section{The Added Value of Oscars and Festival Awards}

This article discusses the value of the Academy Awards and awards received by filmmakers at film festivals, as well as other advantages of participating in them. It does so by taking into consideration several aspects of film awards: their effect on the monetary profit made by the winning films, their effect on the construction of the film canon and the 'cinematic map' of the world. It also examines factors conducive to receiving awards, such as successful marketing campaigns and tackling certain topics, as well as considers the argument that film awards have lost some of their value in recent years. The article is based on secondary research about Oscars and film festivals, a large part of which is based on journalistic sources, reflecting the 
fact that much of the data is new and hence has not yet been properly digested by the academic community.

Keywords: Film festivals, film awards, the Holocaust, Roman Polanski, Jean-Luc Godard

Data otrzymania tekstu: 8.04.2021 r.

Data zakończenia procesu recenzyjnego: 15.05.2021 r.

Data akceptacji tekstu do druku: 24.05.2021 r. 